\title{
Militarne zaangażowanie Niemiec w Afryce - wybrane aspekty
}

\section{Wprowadzenie}

Na obecną politykę Niemiec wobec Afryki w wymiarze bezpieczeństwa wpływają dynamicznie zachodzące zmiany w państwach afrykańskich, uwarunkowane w dużej mierze procesami globalizacyjnymi i demograficznymi. Skala zagrożenia terrorystycznego, niezrównoważone wykorzystanie zasobów, konflikty polityczne w Afryce coraz mocniej oddziałują na percepcję bezpieczeństwa w Niemczech. Arabska Wiosna oraz polityka kanclerz Angeli Merkel wobec kryzysu migracyjnego stały się procesami wpływającymi na politykę wewnętrzną Niemiec. Kontynent postrzegany wcześniej jako oddalony od Bonn i Berlina, w którym Francja i Wielka Brytania były bardziej obecne ze względu na historyczne uwarunkowania, ze względu na skalę i następstwa problemów wymusił na rządzie niemieckim szereg działań. Podejmowane na forach międzynarodowych inicjatywy wobec państw afrykańskich wynikają z potrzeby reagowania na aktualne wydarzenia oraz następstw kształtowania polityki Niemiec wobec Afryki po II wojnie światowej.

Obserwacje i dyskusje dotyczące militarnego zaangażowania Niemiec w Afryce wymagają rozważań o definiowaniu interesów i odpowiedzialności Berlina wobec Afryki. W przeszłości Niemcy nie angażowały się politycznie w Afryce tak bardzo, jak Francja czy Wielka Brytania. To potężne kolonialne mocarstwa najbardziej interesowały się wydarzeniami na Czarnym Kontynencie. Po II wojnie światowej Niemcy deklarowali poczucie historycznej odpowiedzialności za państwa wcześniej znajdujące się w ich strefie wpływów, np. Ruandę czy Burundi. Jedno z podstawowych pytań badawczych wymaga odpowiedzi dlaczego Niemcy są raz aktywne, a raz pasywne w podejmowaniu decyzji dotyczących wojskowego zaangażowania w Afryce oraz w jaki sposób obecnie starają się realizować interesy dotyczące Afryki, kierując się priorytetem multilateralizmu. W tym celu analizowano rządowe strategie, koncepty i wytyczne, a także materiały instytucji prowadzących badania afrykanistyczne, tj. Instytut ds. Studiów Afrykanistycznych w Lipsku, Instytut ds. Badań nad Azją i Afryką w Hamburgu, berlińska Fundacja Nauka i Polityka, Niemieckie Towarzystwo Polityki Międzynarodowej w Berlinie, Centrum ds. Międzynarodowych Operacji Pokojowych w Berlinie. W artykule zastosowano wybrane podejścia badawcze, polegające na analizie dokumentów oraz procesu decyzyjnego na wybranych przykładach (pominięto np. czynnik feministyczny; kwestię finansowania misji oraz eksportu broni).

Polityka Niemiec wobec Afryki w wymiarze bezpieczeństwa ewoluowała. Ulf Engel zaznaczył, że interesy Niemiec wobec Afryki były uwarunkowane sposobem definiowania tożsamości i międzynarodowej roli Niemiec. Wydarzenia dokonujące się 
w Afryce nie były traktowane jako zagrażające bezpieczeństwu Niemiec. W latach siedemdziesiątych Niemcy uważały się za państwo będące cywilną potęgą i swoje działania wytyczały, kierując się określoną dla tejże potęgi rolą (Engel, 2000c). Z czasem Niemcy coraz bardziej dążyły do kompatybilności swojej polityki bezpieczeństwa wobec Afryki z polityką Unii Europejskiej, Organizacji Narodów Zjednoczonych, G-8 oraz innych instytucji międzynarodowych. Luise Richter rozpatrywała w niemieckiej polityce wobec Afryki: 1) realizm, wiarygodność, kompetencje; 2) dopasowanie i harmonizację; 3) potrzebę indywidualnego podejścia do zagadnienia; 4) strategiczne, długoterminowe podejście (Richter, s. 40-41). Z kolei Hermann Kurthen i Helmar Schöne zwrócili uwagę, że standardowo w rozważaniach dotyczących militarnego zaangażowania w Afryce dyskusji poddaje się następujące zagadnienia: 1) kultura militarnego powstrzymywania; 2) orientacja na zobowiązania sojusznicze; 3) zasada multitateralizmu; 4) norma ochrony praw człowieka w oparciu o zasadę odpowiedzialności za ochronę (Responsibility to protect, R2P) (Kurthen, Schöne, 2018, s. 46).

Niemcy długo kierowały się zasadą never alone oraz budowały tzw. cywilną potęgę. Gdy w 2016 roku zostały przeprowadzone badania sondażowe, w których wzięło udział 1001 Niemców, okazało się, że Niemcy oczekują większego zaangażowania w Afryce w takich kwestiach, jak: pomoc rozwojowa i wsparcie finansowe (84\%); inwestycje w gospodarki państw afrykańskich (72\%); opanowanie fali migracyjnej w Afryce (70\%). Te cele wiązały się ze stereotypowym postrzeganiem Afryki jako kontynentu zagrożonego przez konflikty, choroby i kryzysy, ale oddalonego geograficznie i kulturowo od Niemiec. Za interwencjami wojskowymi przeciwko terrorystom w Afryce opowiedziało się tylko $40 \%$ badanych. Spośród badanych $68 \%$ opowiedziało się za większym zaangażowaniem w sprawy Afryki, a 28\% jest przeciwnych (Einsatz, 2016, s. 7). Andreas Rinke zauważył, że w niemieckich dyskusjach dotyczących Afryki panuje „typowy moralizm”, co oznacza, że Niemcy w debacie publicznej opowiadają się za pomocą humanitarną, ale krytykują wojskowe zaangażowanie i eksport broni do Afryki. Dlatego udział militarny Niemiec wymaga międzynarodowego poparcia, zwłaszcza gdy operacje niosą ze sobą ryzyko niepowodzenia (Rinke, s. 8 i 14). Natomiast Olaf Bernau wystosował zarzut: „niemiecka polityka wobec Afryki jest naznaczona europocentryzmem, paternalizmem i bezwzględną polityką interesów (Bernau, 2017, s. 40). Z kolei Lutz Mükke ocenił, że niemieckie medialne relacje dotyczące Afryki opierają się na „negatywizmie, etnocentryzmie, słabej znajomości przyczyn konfliktów oraz stereotypach (Mükke, 2009, s. 39). Konsekwencją kryzysu migracyjnego po 2016 roku było zwiększenie zainteresowania niemieckiego rządu realizacją polityki wobec Afryki, motywowane zarówno interesami gospodarczymi, motywami humanitarnymi, jak i potrzebą wzmocnienia państw afrykańskich, by zmniejszyć presję migracyjną.

\section{Polityka bezpieczeństwa wobec Afryki podczas zimnej wojny}

Niemcy Zachodnie, nie wyrzekając się po 1949 roku dążenia do zjednoczenia Niemiec, decydowały się na współpracę z tymi państwami afrykańskimi, które przestrzegały doktryny Waltera Hallsteina z 1955 roku, która sprowadzała się do zrywania kontaktów dyplomatycznych z państwami uznającymi będące w radzieckiej strefie 
wpływów Niemcy Wschodnie. W 1951 roku nastąpiło otwarcie przez Niemcy Zachodnie konsulatu w Afryce Południowej. Państwa, które wojskowo współpracowały z Niemcami to Etiopia, Gwinea, Kongo, Nigeria, Madagaskar, Senegal, Somalia, Sudan, Tanzania, Czad, Południowa Afryka. Do Niemiec byli wysyłani na kursy szkoleniowe kandydaci na żołnierzy i policjantów z tych państw. Przeszkoleni ludzie byli później potrzebni na misjach ONZ. Skala współpracy była marginalna. Upadek apartheidu przyczynił się do intensyfikacji kooperacji wojskowej z Republiką Południowej Afryki. Następnie Senegal, Ghana, Namibia, Zimbabwe, Burkina-Faso i Benin zdecydowały się na wojskową współpracę z Niemcami, aby usprawnić działania swoich armii. Na przykładzie Nigerii można podsumować, że współpraca wojskowa z państwami afrykańskimi polegała na dostarczaniu sprzętu i szkoleniu żołnierzy. Utworzone w Nigerii w 1963 roku lotnictwo było szkolone w ramach kontraktu przez niemieckich lotników - Colonelsa G. Kathza i W. Rhiminga. Kontrakt dotyczący szkoleń lotnictwa został wypowiedziany, gdy rząd Nigerii zaczął współpracować w tym zakresie z ZSRR. Niemiecki przemysł zbrojeniowy w ramach kontraktów dostarczył do Nigerii m.in. kilka myśliwców Alpha Jet i fregatę. Bez efektu zakończyły się rokowania niemiecko-nigeryjskie w sprawie budowy reaktora atomowego. Na kontrakty wojskowe z Nigerią wpływała niestabilność polityczna regionu oraz rywalizacja zimnowojenna (Durotoye, 2001, s. 108-109). W latach siedemdziesiątych w Niemczech Zachodnich Afryka była przedstawiana stereotypowo, jako zapomniany i biedny kontynent, który wymaga prawidłowo określonej polityki rozwojowej.

Willy Brandt, minister spraw zagranicznych w latach 1966-1969 kierował się wobec państw afrykańskich zasadą nieingerencji w sprawy wewnętrzne innych państw. W 1978 roku Helmut Schmidt przedstawił postulaty wyznaczające ramy polityki RFN wobec Afryki:

1) pokój i stabilność mogą prosperować na bazie wolności, którą zdobywa się nie tylko przez dekolonizację, ale także rozwój ekonomii;

2) rozwiązywanie konfliktów w Afryce środkami pokojowymi;

3) respektowanie granic;

4) wyrzeczenie się siły w rozwiązywaniu politycznych i gospodarczych problemów;

5) zasada nieingerencji w wewnętrzne sprawy państw (Durotoye, 2001, s. 115).

Przyjęcie Niemiec Wschodnich i Zachodnich w 1973 roku do ONZ spowodowało, że Niemcy Zachodnie zaczęły działać na rzecz rozwiązywania konfliktów w ramach tej organizacji, jednak nadal polityka ,zdobywania sojuszników i rynków” stanowiła priorytet. Przykładem aktywności NRD i RFN była misja UNTAG (United Nations Transition Assistance Group) w Namibii (dawnej niemieckiej kolonii) i Angoli. Misja została przeprowadzona na podstawie rezolucji ONZ nr 632 z 1989 roku.

\section{Priorytet multilateralizmu po zjednoczenie Niemiec}

Po zakończeniu zimnej wojny i zjednoczeniu Niemiec sojusznicy zaczęli wymagać od Niemiec, aby przyjęły obowiązek partycypowania w międzynarodowych operacjach pokojowych. Niemcy swoją politykę zamierzały realizować w myśl haseł: „,nigdy samotnie” (,never alone”), „nigdy więcej” (,never again”), „polityka przed 
siłą" (,politics before force"). Warunkami partycypacji Niemiec w misjach były: mandat ONZ dla misji, zgoda rządu wewnętrznego oraz zgoda niemieckiego parlamentu, a także terytorialne i czasowe ograniczenie misji. Bundeswehra angażowała się w Afryce od lat sześćdziesiątych XX wieku. Obecność żołnierzy w 1960 roku w marokańskim Agadirze wiązała się z niesieniem pomocy po trzęsieniu ziemi. Żołnierze niemieccy przebywali w 1984 roku w Etiopii w związku z trwającą tam klęską głodu, w 1994 roku 30 żołnierzy Bundeswehry wysłano na misję UNAMIR (United Nations Assistance Mission in Rwanda) w Ruandzie, Kenii, Afryce Południowej, Zairze.

Partycypowanie niemieckich żołnierzy w latach 1993-1994 w misji ONZ w Somalii (United Nations Operation in Somalia II) było wyjściem naprzeciw oczekiwaniom USA, aby Niemcy nie tylko poprzez dyplomację książeczki czekowej, ale także personalny wkład wywiązywali się ze zobowiązań sojuszniczych. Helmut Kohl wspominał, że podczas debaty w Bundestagu na temat wyrażenia zgody na operację UNOSOM politycy wyrażali obawy przed militaryzacją Niemiec. Zdaniem kanclerza te obawy były „absurdalne” (Kohl, 2007, s. 570). Po wyroku niemieckiego Trybunału Konstytucyjnego z 12 VII 1994 roku udział Bundeswehry w misjach w ramach zbiorowych systemów bezpieczeństwa stał się możliwy pod warunkiem uzyskania zgody parlamentu. Jednak Niemcy rozważnie podejmowali decyzje dotyczące angażowania się w misje out of area, chociaż udział Bundeswehry w misjach wojskowych tłumaczono jako „normalizację” niemieckiej polityki bezpieczeństwa. Francuskiemu ministrowi spraw zagranicznych Philippe Léotardowi nie udało się przekonać ministra Volkera Rühe do wykorzystania żołnierzy z Eurokorps w misjach wojskowych w Afryce. Niemiecki minister, nawiązując do wydarzeń z II wojny światowej, twardo oświadczył, że niemieccy żołnierze nie staną się częścią Afrikakorps. Dopiero następstwa Arabskiej Wiosny spowodowały, że niemieccy dyplomaci i politycy, tj. Wolfgang Ischinger i Ursula von der Leyen przeciwstawili się opinii V. Rühe i zaczęli twierdzić, że ze względu na przyrost zagrożeń w Afryce Eurokorps może stać się Afrikakorps.

\section{Prymat polityki gospodarczej nad polityką bezpieczeństwa}

Sprawa kształtowania polityki wobec Afryki wydawała się nawet wielu praktykom polityki zagranicznej czasami obca. Doradca kanclerza Helmuta Kohla pytał: „Dlaczego byliśmy obecni w Kongo, a nie w Darfurze? [...] Czy wyjaśniono nam, czy Afryka jest dla nas ważna, czy nie? Czy Afryka ma dla nas strategiczne znaczenie, czy też nie? Czy to wszystko, czego jesteśmy świadkami nie jest przypadkowe? Dlaczego nie widzimy w Niemczech żadnej publicznej debaty na ten temat?" (Teltschik, s. 14).

Spośród niemieckich ministerstw najwięcej inicjatyw wysuwało ministerstwo ds. rozwoju, które przedstawiło w 1991 roku wytyczne w sprawie Afryki:

1) tylko państwa afrykańskie, które ogłosiły, że wprowadzą reformy gospodarcze i będą przestrzegały zasad demokratycznych otrzymają specjalne wsparcie Niemiec;

2) afrykańskie państwa muszą przestrzegać elementarnych standardów praworządności, praw człowieka, partycypacji;

3) rząd niemiecki ma wspierać przestrzeganie demokracji; 
4) Niemcy wspierają decyzje UE w zakresie polityki pomocowej wobec Afryki;

5) wsparcie prewencyjnego zapobiegania konfliktom;

6) wsparcie misji szkoleniowych, redukowanie biedy, ochrona środowiska;

7) intensyfikacja współpracy kulturowej.

Jak podsumował Ulf, Engel cele ministerstwa rozwoju uwzględniały 5 priorytetów, którymi były: 1) poprawa zarządzania, demokratyzacja, przestrzeganie praw człowieka; 2) przeciwdziałanie i walka z następstwami przemocy; 3) inwestowanie w kapitał ludzki; 4) wspieranie zdolności ekonomicznych i integracja regionalna; 5) wspieranie zrównoważonego rozwoju (Engel, 2007). W 1993 roku zostało ogłoszonych 10 wytycznych z Akry w Ghanie. Był to dokument niemieckiego urzędu spraw zagranicznych, w którym zaznaczono, że współpraca z Afryką opiera się na zasadzie warunkowości (principles of conditionality). Niemcy uzależniali działalność w Afryce od oceny stanu przestrzegania praw człowieka, wdrażania rządów prawa, partycypacji oraz realizacji polityki gospodarczej. Stąd państwa takie jak Liberia, Malawi, Togo, Kenia ze względu na niewywiązanie się z niemieckich kryteriów zostały wyłączone ze współpracy (Engel, 2000a, s. 116; Durotoye, 2001, s. 110). Na początku lat dziewięćdziesiątych Niemcy pokładali nadzieję, że utworzenie Unii Afrykańskiej oraz realizacja Nowego Partnerstwa dla Rozwoju Afryki wpłyną pozytywnie na proces reformowania Afryki, z udziałem Unii Europejskiej oraz G-8 (Schukraft, 2007, s. 196). W latach dziewięćdziesiątych ze względu na nieustawanie konfliktów w byłych niemieckich koloniach Burundi i Ruandzie, sprawa polityki wobec państw afrykańskich była przedmiotem parlamentarnych dyskusji, chociaż niemieccy decydenci interesowali się bardziej konfliktami w innych regionach, np. na Bałkanach. W przeprowadzonej w 1997 roku w Bundestagu dyskusji Frakcja Zielonych postulowała opartą na zasadzie solidarności politykę wobec Afrykańczyków, polegającą na zapobieganiu kryzysom i zwracaniu uwagi na regionalne zróżnicowanie Afryki. Jednak postulaty frakcji zostały paradoksalnie zarzucone przez polityka z tego ugrupowania - Joschkę Fischera, gdy w 1998 roku został ministrem spraw zagranicznych. Nowy minister dość marginalnie traktował konflikty afrykańskie na tle innych wydarzeń międzynarodowych, np. konflikt w Kosowie (Schukraft, 2007, s. 208).

Koalicja SPD i Zielonych po 1998 roku realizowała w ramach koncepcji civil power politykę rozwojową w Afryce, która byłaby kompatybilna z polityką Unii Europejskiej oraz światowym porządkiem gospodarczym. 27 stycznia 1999 roku Joschka Fischer przedstawiając założenia polityki wobec Afryki uwzględnił zarządzanie kryzysowe i potrzebę dbałości o prawa człowieka. Polityka wobec Afryki została wpisana do agendy niemieckiej prezydencji w Unii Europejskiej w 1999 roku. Jej konceptualizacja odbywała się także w ramach podróży dyplomatycznych, np. wizyty w marcu 2000 roku J. Fischera w Afryce. Polityk zaznaczył, że sukces niemieckiej współpracy gospodarczej jest uzależniony od postępów w umacnianiu stabilności i przestrzegania praw człowieka w Afryce (Engel, 2000b).

W 2000 roku sześciu niemieckich akademików - Ulf Engel, Robert Kappel, Stephan Klingebiel, Stefan Mair, Andreas Mehler i Siegmar Schmidt wystosowali memorandum, postulując określenie na nowo niemieckiej polityki wobec Afryki. Podkreślili znaczenie realizowania polityki rozwojowej w Afryce oraz budowania strukturalnej stabilności. Komentujący raport niemiecki dziennikarz Bartholomäus Grill zaznaczył, że eksperci zaliczyli do wschodzących gospodarek afrykańskich tylko Seszele i Mau- 
ritus, a do państw gotowych na przeprowadzenie reform - Ghanę, Republikę Zielonego Przylądka, Gwineę Równikową, Gabun, Botsuanę, Namibię, Lesotho, Republikę Środkowej Afryki (Durotoye, 2001, s. 124; Grill, 2012, s. 54).

Chociaż w rządzie G. Schrödera Afryka była postrzegana przede wszystkim przez pryzmat ekonomii, to w 2000 roku uchwalony Koncept „Cywilne Zapobieganie Kryzysom, Rozwiązywanie Konfliktów i Konsolidacja Pokoju” nadawał kierunek działaniom wobec państw afrykańskich. Na podstawie jednostronicowego dokumentu tworzono w następnych latach plany działań antykryzysowych, także dla państw upadłych. Wśród najważniejszych gwarantów stabilności w dokumencie wymienione zostały: sprawiedliwość społeczna, przestrzeganie praw człowieka, praworządność, partycypacyjny proces decyzyjny, troska o zasoby naturalne, szanse na rozwój (Gesamtkonzept, 2000).

W 2001 roku kierowany przez J. Fischera niemiecki urząd spraw zagranicznych przedstawił strategię działań wobec Afryki, w której została wyszczególniona potrzeba dostrzegania regionalnych różnic i uwarunkowań. Urząd ds. zagranicznych wyróżnił 5 regionów - południowy, wschodni, zachodni, Róg Afryki i Afrykę Centralną. Taki podział miał gwarantować skuteczniejsze i bardziej efektywne podejmowanie decyzji politycznych (Koepf, 2015, s. 8).

Przeprowadzony 11 IX 2001 roku atak na World Trade Center wpłynął na wzrost analiz, które uwzględniały zagrożenie terrorystyczne. W 2002 roku Niemcy zaczęły partycypować w wymierzonej przeciwko islamistom i piratom operacji Enduring Freedom w Rogu Afryki.

Trwający od 1 do 3 czerwca 2003 roku Szczyt G-8 w Evian-les-Bains we Francji z udziałem przedstawicieli Egiptu, Nigerii, Senegalu i Republiki Południowej Afryki potwierdził cele niemieckiej polityki rozwojowej i pokazał, w jakim kierunku potoczy się niemiecka polityka wobec Afryki. Trwała także debata publiczna o afrykańskich konfliktach, gdzie spierali się zwolennicy i oponenci polityki zaangażowania. Szczyt G-8 firmował i uwiarygadniał dwie inicjatywy wobec Afryki: Nowe Partnerstwo dla Rozwoju Afryki (NEPAD) oraz powołanie afrykańskich regionalnych sił szybkiego reagowania. Afrykańskie siły pokojowe miały do 2010 roku osiągnąc liczebność od 3000 do 3500 ludzi (Gradziuk, 2003; Eid, Asche, 2003). Rząd SPD/Zielonych nadal skupiał się na polityce rozwojowej w Afryce, a sprawy bezpieczeństwa traktował marginalnie.

Program wizyty kanclerza G. Schrödera oraz Uschi Eid, niemieckiej pełnomocnik ds. Afryki i przedstawicielki Zielonych w Etiopii, Kenii, Afryce Południowej i Ghanie (18-24 I 2004 roku) zdominowały sprawy gospodarcze. Zaplanowana na marzec podróż G. Schrödera do Afryki nie odbyła się z powodu groźby ataku terrorystycznego (Schölgen, s. 569, 747-750). W postulowanym w 2005 roku przez prezydenta Horsta Köhlera „Partnerstwie z Afryką” polityce bezpieczeństwa poświęcono niewiele uwagi (von $\mathrm{Na}$, Grill, 2005).

\section{Wymiar bezpieczeństwa na forum Unii Europejskiej}

Polityka bezpieczeństwa Niemiec wobec państw afrykańskich często stanowiła przedmiot sporów. Niemiecka polityka ds. bezpieczeństwa była charakteryzowana jako europocentryczna, a francuska jako globalna. Ważnym graczem była także 
Wielka Brytania, która ostrożnie i powoli godziła się na wzrost roli Unii Europejskiej w sprawach polityki obrony. Jacques Chirac uzyskał od Tonny’ego Blaira na szczycie w Saint Malo w 1998 roku zielone światło dla rozwijania polityki obronnej. Następnym krokiem w kierunku porozumienia francusko-brytyjskiego były obchody w 2004 roku stulecia entente cordiale. Dlatego współpraca w ramach misji między Niemcami i innymi sojusznikami zależała zawsze od przetargów i sposobu definiowania interesów przez zainteresowanych aktorów. Przełomowym działaniem rządu G. Schrödera była decyzja, by partycypować w pierwszej unijnej operacji wojskowej o kryptonimie ARTEMIS w 2003 roku. Inicjatorką misji, która miała wesprzeć misję MONUC (Mission des Nations Unies en République Démocratique du Congo) była Francja. Sukces misji przyczynił się do uchwalenia ,Wspólnego Stanowiska z 26 stycznia w sprawie Afryki" przez Radę Unii Europejskiej (Wojnicz, 2014, s. 273). Po objęciu władzy w 2005 roku przez rząd wielkiej koalicji CDU/CSU i SPD Niemcy podjęły decyzję o uczestniczeniu w misji wojskowej EUFOR w Kongo od 30 VII do 30 XI 2006 z udziałem 780 żołnierzy. Niemiecki generał Karlheinz Viereck objął dowództwo nad całą misją, która liczyła 2400 żołnierzy z 23 państw. Celem misji było wsparcie operacji MONUC w przeprowadzeniu wolnych wyborów w Kongo. Niemieckie społeczeństwo wyrażało sceptycyzm wobec uczestniczenia w misji. Także lider Wolnej Partii Demokratycznej Guido Westerwelle oceniał, że jest ryzykowna i skazana na klęskę, ponieważ uczestnikom misji nie uda się ustabilizować sytuacji na tak dużym obszarze, jakim jest Kongo. G. Westerwelle kierował się kulturą powstrzymywania i odradzał angażowanie się w problemy Konga. Ministrowi obrony Franzowi Josefowi Jungowi zarzucano, że ma za mało doświadczenia w podejmowaniu decyzji dotyczących afrykańskich konfliktów (Demokratische...; Møller, 2015, s. 44-50; Sattar, 2009, s. 265).

W latach 2007-2008 misja wojskowa EUFOR Czad/Republika Środkowej Afryki odbyła się bez udziału Niemiec, którzy zdecydowali się wyrazić wyłącznie polityczne poparcie wobec inicjowanej przez Francję interwencji w Czadzie i Republice Środkowej Afryki, uważając, że Paryż realizuje własne interesy w byłych koloniach. Wojsko francuskie było obecne w Czadzie od 1986 roku. Kanclerz A. Merkel podczas spotkania we wrześniu 2007 roku z N. Sarkozy'm (który w tym samym roku przejął prezydenturę po J. Chirac’u) zwracała też uwagę, że niemieckie społeczeństwo jest sceptyczne wobec inicjatywy wysłania żołnierzy do Czadu i RŚA. Mimo że Niemcy byli przeciwnikami misji, to nie zawetowali decyzji Rady Unii Europejskiej z 15 X 2007 roku o ustanowieniu misji EUFOR (Møller, 2015, s. 51-55).

W Koncepcie Rządu Niemieckiego w sprawie Afryki z 2011 roku bezpieczeństwo i rozwój zostały potraktowane jako dominujące cele, umożliwiające rozwój innych relacji między Niemcami i państwami z Afryki. Niemcy opowiadali się za umacnianiem instrumentów przezwyciężających konflikty i napięcia w Afryce, które umożliwiałyby coraz bardziej samodzielne działania i własne inicjatywy rządów afrykańskich. Wyrażali poparcie dla działań Unii Afrykańskiej, Wspólnoty Gospodarczej Państw Afryki Zachodniej (ECOWAS), Wspólnoty Wschodnioafrykańskiej (EAC), Międzyrządowej Władzy ds. Rozwoju (IGAD), Wspólnoty Rozwoju Afryki Południowej (SADC), jednostek wojskowych w Afryce Wschodniej (EASFCOM), Afrykańskiej Architektury Pokoju i Bezpieczeństwa (APSA) oraz rozwijania regionalnych jednostek wojskowych (African Standby Force). Jednocześnie opowiadali się za dalszym wzmacnianiem bez- 
pieczeństwa w Afryce poprzez działania ONZ. Zwrócili uwagę, że Niemcy wspierali ONZ w następujących inicjatywach od 2008 do 2010 roku:

1) UNMIL w Liberii (wkład finansowy i 5 cywilnych przedstawicieli);

2) MINURSO w Afryce Zachodniej (wkład finansowy);

3) MONUC/MONUSCO w Kongo (wkład finansowy i 10 cywilnych przedstawicieli);

4) UNOCI na Wybrzeżu Kości Słoniowej (wkład finansowy i 1 cywilny przedstawiciel);

5) UNMIS w Sudanie (wkład finansowy; 22 żołnierzy, 7 policjantów, 11 cywilnych przedstawicieli);

6) UNAMID w Darfurze (wkład finansowy, 9 żołnierzy, 5 policjantów, 2 cywilnych przedstawicieli);

7) MINURCAT w Republice Środkowej Afryki i Czadzie (wkład finansowy i 1 cywilny przedstawiciel);

8) AMISON/UNSOA w Somalii (wkład finansowy).

W 2012 roku w Niemczech zostały zatwierdzone rządowe wytyczne dla koherentnej polityki wobec państw upadłych. Dokument ten był kontynuacją analiz z zatwierdzonego w 2004 roku dokumentu „Cywilne zapobieganie sytuacjom kryzysowym, rozwiązywanie konfliktów i budowanie pokoju” oraz Białej Księgi z 2006 roku. Niemcy zaznaczyli, że działania wobec państw upadłych mają wynikać z zasady multilateralizmu oraz być prowadzone we współpracy z regionalnymi instytucjami. Docenienie roli organizacji regionalnych wiązało się ze świadomością znaczenia różnic kulturowych oraz słabości struktur i potencjału państw afrykańskich. Część z nich została zaliczona do grupy państw upadłych. Decydenci zauważali, że przedstawiciele instytucji, którzy znają teren objęty konfliktem będą działać skuteczniej. W dokumencie jako przykładowe państwo upadłe został wymieniony Sudan. Niemcy zalecali następujące działania wobec takich podmiotów: wczesne przeprowadzenie analizy położenia i struktur władzy z użyciem think thanków i zewnętrznych fachowych ekspertyz; regularne informowanie rządu o sytuacji na miejscu; sformułowanie jasnych celów i kryteriów niemieckiego zaangażowania (benchmarking); uzgadnianie działań między resortami; działanie zgodne z międzynarodowymi ustalaniami oraz partnerami w regionie objętym kryzysem (Für eine kohärente...).

Niemcy opowiedzieli się za polityką zwalczania i zapobiegania terroryzmowi, np. poprzez działania Unii Europejskiej. Podkreślili, że uczestniczyli od 2008 roku w misji wojskowej UE Atalanta w Zatoce Adeńskiej. Celem misji była walka z piractwem. Do innych działań zaliczyli uczestniczenie w projektach kontroli walki bronią oraz walki z zagrożeniami spowodowanymi minami (Deutschland..., 2011).

Wybuch Arabskiej Wiosny i dążenia do obalenia Muammara Kaddafiego w Libii w Niemczech przyjęto pozytywnie. Będąc niestałym członkiem Rady Bezpieczeństwa Niemcy poparły rezolucję ONZ nr 1970 z 26 II 2011 roku w sprawie wprowadzenia sankcji oraz embarga na broń wobec Libii. 27 lutego Niemcy wraz z Wielką Brytanią rozpoczęły wojskową operację Pegasus, której celem była ewakuacja europejskiej ludności cywilnej z Mali. Gdy Liga Arabska wraz z Francją zaczęły domagać się wprowadzenia strefy zakazu lotów nad Libią, Niemcy zaczęły prezentować sceptyczne stanowisko. G. Westerwelle przypominał, że misja wojskowa Niemiec wymaga zgody Rady Bezpieczeństwa ONZ i powinna odbywać się w porozumieniu z partnerami w regionie. Mimo spełnienia tych kryteriów Niemcy wstrzymały się, podobnie jak 
Brazylia, Chiny, Indie, Rosja od głosu nad rezolucją nr 1973, której celem było wprowadzenie strefy zakazu lotów nad Libią. Stanowisko Niemiec było niejasne, gdyż Angela Merkel tłumaczyła, że wstrzymanie się od głosowania nad rezolucją nie oznacza poparcia dla reżimu Kaddafiego. Brak wyraźnego i czytelnego wyrażenia poparcia dla polityki Francji i Wielkiej Brytanii został potraktowany jako przełom przez polityków, naukowców i innych komentatorów zainteresowanych polityką międzynarodową. Politolog Christian Hacke zarzucił politykom z gabinetu CDU/CSU i FDP, że odcięli się od sprawdzonych sojuszników. Dyplomata Wolfgang Ischinger wstrzymanie się Niemiec od głosu w sprawie rezolucji ONZ nr 1973 uznał za niestosowne. Także minister Joschka Fischer zarzucił Guido Westerwellemu popełnienie błędu w polityce wobec Afryki. Liberał odpierał krytykę i prezentował stanowisko, że Niemcy nie powinny angażować się w wojnę domową w Libii. Mimo krytycznych głosów, 3 marca 2011 roku została zamknięta niemiecka ambasada w tym państwie, przedstawiciele niemieckiego przemysłu powrócili do domów. Decyzje podjęte w sprawie Libii osłabiły pozycję liberałów w rządzie A. Merkel. W przeprowadzonych 27 III 2011 roku wyborach FDP otrzymała w Badenii Wirtembergii 5,3\% poparcia, a w Nadrenii Palatynacie 4,2\%. G. Westerwelle wytrwale prezentował negatywne stanowisko wobec militarnego zaangażowania w Afryce (Møller, 2015, s. 56-65; Hanisch, 2015, s. 109-114).

Destabilizacja Mali w 2012 roku, spowodowana przejęciem kontroli nad częścią terytorium przez Al Qaidę i wprowadzaniem rządów szariatu została przyjęta przez Unię Europejską z obawami. We wrześniu 2012 roku został obalony prezydent Mali Dioncounda Traoré. Jego następca, Ibrahim Boubacar Keïta wystosował do Unii Europejskiej prośbę o wsparcie. Sprawą Mali zajęła się także ONZ, a Francja zdecydowała, by rozpocząć unilateralną interwencję w dawnej kolonii. W niemieckim gabinecie kwestia Mali wywołała spory, powodowane m.in. obawą, że Mali stanie się tzw. drugim Afganistanem, terytorium które jest trudno opanować zewnętrznym aktorom międzynarodowym. Stąd A. Merkel zaczęła promować doktrynę Enable and Enhance (E2E). Ta inicjatywa polegała na szkoleniu przez siły UE przedstawicieli miejscowej ludności, którzy znają lepiej obszar objęty konfliktem. Na forum Rady UE w październiku zaczęto tworzyć plan wojskowej misji szkoleniowej w Mali, która byłaby kompatybilna ze strategią UE ds. bezpieczeństwa i rozwoju regionu Sahelu. Podczas gdy A. Merkel 22 X 2012 roku opowiedziała się za udziałem Niemiec w misji szkoleniowej UE, dzień później minister G. Westerwelle wykluczył udział niemieckich żołnierzy i w zamian obiecał udostępnienie dwóch samolotów. Mimo sceptycyzmu Niemiec w styczniu na forum UE wyrażono wsparcie dla operacji AFISMA oraz operacji Serval, działającej pod auspicjami Francji i państw afrykańskich. Przyjęcie przez Radę Bezpieczeństwa ONZ rezolucji 2071 i 2085 było dla UE podstawą dla zorganizowania misji. Negocjacje w sprawie Mali toczyły się do 18 II 2013 roku, gdy Rada Unii Europejskiej zdecydowała o rozpoczęciu misji EUTM Mali, pod kierunkiem francuskiego generała Françoisa Lecointre. 28 II Bundestag zezwolił na roczny udział Niemiec w misji EUTM Mali. W Niemczech uważano, że stabilność regionu Sahelu zależy od sytuacji w Mali.

W celu odkreślenia sojuszu z Francją Niemcy wspierały na forum UE ich politykę wobec Republiki Środkowej Afryki, chociaż nie wiązały z tym państwem interesów. Niemiecka ambasada w Bangi została zamknięta w 1997 roku. Wskutek przewrotu dokonanego przez ugrupowanie Seleka prezydent Françoise Bozizé 15 III 2013 roku opu- 
ścił państwo. Wskutek polityki Francji ministrowie spraw zagranicznych UE opowiedzieli się 20 I 2014 roku za uruchomieniem misji wojskowej w Republice Środkowej Afryki. 25 II 2014 roku rząd niemiecki zgodził się wysłać żołnierzy w celu wsparcia misji do kwatery głównej w Grecji oraz do Bangi. Misja rozpoczęła się 1 IV 2014 roku.

22 września 2013 roku odbyły się w Niemczech wybory, które przyniosły władzę koalicji CDU/CSU i SPD. Przejęcie przez Ursulę von der Leyen ministerstwa obrony wpłynęło na pojawienie się nowych inicjatyw dotyczących Afryki. Przede wszystkim pod wpływem Arabskiej Wiosny nowa minister zaczęła opowiadać się za większym udziałem Niemiec w międzynarodowych misjach ds. zapobiegania kryzysom. U. von der Leyen szczególnie optowała m.in. za zaangażowaniem Niemiec w misji wojskowej w Mali.

Na początku 2014 roku podczas organizowanej corocznie międzynarodowej konferencji ds. bezpieczeństwa w Monachium minister ds. obrony U. von der Leyen i minister ds. zagranicznych F.-W. Steinmeier postulowali więcej odpowiedzialności Niemiec za zarządzanie kryzysowe oraz zwiększeniem partycypacji w działania wojskowe w Afryce. Minister Steinmeier tłumaczył, że Niemcy nie mogą prowadzić polityki reaktywnej, gdyż są zbyt silnym państwem. Także prezydent Joachim Gauck polemizując $\mathrm{z}$ wypowiedziami przeciwko militaryzacji niemieckiej dyplomacji zaznaczył, że Niemcy powinny prowadzić bardziej aktywną politykę. Polityk zwrócił uwagę, że wskazywanie na historyczne winy Niemiec jako argument przemawiający za zasadą nieinterwencji jest anachroniczne. Elity polityczne opowiedziały się w Monachium za zastąpieniem kultury powstrzymywania normalizacją, by Niemcy traktować jako odpowiedzialnego sojusznika oraz „,normal ally” (Hanisch, 2015, s. 14-17).

W maju 2014 roku zostały przedstawione wytyczne rządu wobec Afryki. Olaf Bernau zaznaczył, że w tym dokumencie rządowym pierwszy raz Afryka ,została zdefiniowana jako kontynent szans, a nie kryzysów" (Bernau, 2017, s. 37). Na piętnastu stronach zaznaczono, że Afryka znajduje się w przełomowym stadium. Główna teza zawierała się w stwierdzeniu, że Afryka potrzebuje własnych osiągnięć i odpowiedzialności za siebie, jednak Niemcy i Europa są gotowe wspierać państwa afrykańskie, które postrzegają jako partnerów. Dlatego Niemcy zadeklarowali wspieranie aktywności Unii Afrykańskiej i innych organizacji regionalnych na rzecz przezwyciężania kryzysów. Współpraca między państwami z obu kontynentów miała być zgodna z zasadami funkcjonowania Unii Europejskiej i ONZ. Ponadto Niemcy poparli postulat umacniania partnerstwa G7/G8 z Afryką. Niemcy zwrócili uwagę na wzrost potencjału Afryki (przede wszystkim demograficznego) oraz potrzebę umacniania stabilności w Afryce. Do słabych stron Afryki zaliczyli niestabilność instytucji, konflikty i kryzysy, a także terroryzm. Rząd podkreślił wzrost zainteresowania Afryką ze strony państw tj. Chiny, Indie, Turcja, Brazylia, Japonia, USA. Postulował umacnianie regionalnej integracji w Afryce oraz rozbudowę niemieckiej usieciowionej i skoordynowanej polityki wobec Afryki, opartej na licznych przedstawicielstwach i instrumentarium tworzonym wspólnie z UE i ONZ. Niemcy zaznaczyli, że ich polityka wobec Afryki zwiera się w ramach UE działania tj.: Partnerstwo UE-Afryka, spotkania na szczycie, promowanie Afrykańskiej Architektury Pokojowej i Bezpieczeństwa. Instrumentarium UE to: Wspólna Polityka Zagraniczna i Bezpieczeństwa, Wspólna Polityka Bezpieczeństwa i Obrony, Europejski Fundusz Rozwoju, Frontex, Instrument na rzecz Pokoju w Afryce, Instrument na rzecz Stabilności i Pokoju, Instrument Rozwoju Współpracy. Współ- 
praca z ONZ opiera się na instytucjach typu Międzynarodowy Fundusz Walutowy, Bank Światowy, Afrykański Bank Rozwoju (Afrikapolitische..., 2014; Koepf, 2015).

W 2015 roku Niemcy przejęły kierownictwo nad misją EUTM Mali, zaangażowały się także w misję cywilną EUCAP (European Union Capacity Building Mission) Sahel Mali, a także wspierały misję MINUSMA. Niemieccy politycy, Joachim Gauck oraz U. von der Leyen wyrażali poparcie dla niemieckiego zaangażowania w Mali podkreślali potrzebę niesienia pomocy humanitarnej Afrykańczykom.

Ze struktury poświęconej problemom bezpieczeństwa Białej Księgi niemieckiego rządu z 2016 roku wynikało, że zaangażowanie militarne Niemcy rozważają wyłącznie w ramach zobowiązań sojuszniczych. Mimo intensyfikacji kontaktów niemiecko-afrykańskich, liczba konfliktów skuteczność działań na rzecz stabilizacji Afryki jest marginalna. Przeciwnicy partycypacji w misjach wojskowych UE podnoszą argument, że przeszkoleni przez żołnierzy z demokratycznych państw Afrykańczycy będą wykorzystani przez ugrupowania terrorystyczne i wpłyną na dalszą destabilizację kontynentu. Ponadto państwa afrykańskie nie zawsze zwracają się do ONZ, czy innych organizacji o pomoc w przeprowadzeniu działań stabilizacyjnych, co wynika z ich słabości, czasem upadku. Wg badań Instytutu ds. Badania Konfliktów Międzynarodowych w Heidelbergu Afryka cierpi z powodu wojen wywołanych uwarunkowaniami postkolonialnymi; wojen o terytoria; wojen secesyjnych; wojen antyreżimowych; konfliktów asymetrycznych, etnicznych oraz wojen wzniecanych przez islamskich terrorystów (Tetzlauf, 2018, s. 262).

Tabela 1

Wojny i inne konflikty w Afryce w 2016 roku

\begin{tabular}{|c|c|c|c|}
\hline Wojna & Przyczyny & $\begin{array}{c}\text { Bardziej ograniczony kon- } \\
\text { flikt (cechuje go mniejsza } \\
\text { skala zniszczeń wg Instytutu } \\
\text { ds. Badań nad Konfliktami } \\
\text { w Heidelbergu) } \\
\end{array}$ & Przyczyny \\
\hline $\begin{array}{l}\text { Nigeria (Rolnicy/ho- } \\
\text { dowcy bydła) }\end{array}$ & $\begin{array}{l}\text { Regionalna hegemo- } \\
\text { nia, zasoby }\end{array}$ & Kongo (ADF) & $\begin{array}{l}\text { Regionalna hegemo- } \\
\text { nia, zasoby }\end{array}$ \\
\hline $\begin{array}{l}\text { Nigeria/Kamerun/Ni- } \\
\text { ger/Czad (Boko Haram) }\end{array}$ & System/ideologia & Kongo (Bantu-Twa) & $\begin{array}{l}\text { Regionalna hegemo- } \\
\text { nia }\end{array}$ \\
\hline $\begin{array}{l}\text { Somalia/Kenia } \quad \text { (Al. } \\
\text { Shabaad) }\end{array}$ & & Kongo (Mai-Mai i inne) & $\begin{array}{l}\text { Regionalna hegemo- } \\
\text { nia, zasoby }\end{array}$ \\
\hline Sudan (Darfur) & Autonomia, zasoby & Kongo/Ruanda & $\begin{array}{l}\text { Władza państwowa, } \\
\text { regionalna hegemo- } \\
\text { nia, zasoby }\end{array}$ \\
\hline $\begin{array}{l}\text { Sudan (SPML/A-North/ } \\
\text { Südkordofan/Blue Nile) }\end{array}$ & Autonomia, zasoby & Nigeria (Północ-Południe) & $\begin{array}{l}\text { System, ideologia, } \\
\text { władza państwowa }\end{array}$ \\
\hline $\begin{array}{l}\text { Sudan Południowy (róż- } \\
\text { ne grupy etniczne) }\end{array}$ & Autonomia, zasoby & Sudan (różne grupy etniczne) & $\begin{array}{l}\text { Regionalna hegemo- } \\
\text { nia, surowce }\end{array}$ \\
\hline $\begin{array}{l}\text { Sudan Południowy } \\
\text { (SPML/A-IO) }\end{array}$ & $\begin{array}{l}\text { System, ideologia, wła- } \\
\text { dza państwowa, zasoby }\end{array}$ & $\begin{array}{l}\text { Republika Afryki Środkowej } \\
\text { (Anti-Balaka-Ex Séléka) }\end{array}$ & $\begin{array}{l}\text { Władza państwowa, } \\
\text { zasoby }\end{array}$ \\
\hline Libia (opozycja) & $\begin{array}{l}\text { System. Ideologia, } \\
\text { władza państwowa }\end{array}$ & $\begin{array}{l}\text { Egipt (Islamiści/ } \\
\text { Sinai-Halbinsel) } \\
\end{array}$ & System, ideologie \\
\hline
\end{tabular}

Źródło: R. Tetzlaff, Afrika. Eine Einführung in Geschichte, Politik und Gesellschaft, Wiesbaden 2018, s. 264. 
Mimo tak dużej skali konfliktów, aktywność Niemiec jest ograniczona do wybranych obszarów, co wynika ze zobowiązań sojuszniczych. Część obszarów jest tak zdestabilizowana, że nie spełnia kryterium rozpoczęcia misji, jakim jest skuteczne i wiarygodne wystosowanie prośby o pomoc przez miejscową władzę do organizacji międzynarodowej. Także liczebny udział żołnierzy w misjach w Afryce jest w dużej mierze niewystarczający, by zagwarantować bezpieczeństwo.

Tabela 2

Udzial Niemiec w operacjach wojskowych w Afryce wg danych z 7 I 2019 roku

\begin{tabular}{||l|l|c|c|c|c||}
\hline \multicolumn{1}{|c|}{ Operacja } & \multicolumn{1}{|c|}{ Obszar } & $\begin{array}{c}\text { Liczba } \\
\text { zołnierzy }\end{array}$ & I mandat & $\begin{array}{c}\text { Aktualny } \\
\text { mandat }\end{array}$ & $\begin{array}{c}\text { Koniec } \\
\text { mandatu misji }\end{array}$ \\
\hline UNMISS & Sudan Południowy & 13 & 8 VII 2011 & 22 III 2018 & 31 III 2019 \\
\hline UNAMID & Sudan & 4 & 15 XI 2007 & 22 III 2018 & 31 V 2019 \\
\hline EUTM MALI & Mali & 161 & 28 II 2013 & 26 IV 2018 & 31 V 2019 \\
\hline MINUSMA & Mali & 86 & 28 II 2013 & 26 IV 2018 & 31 V 2019 \\
\hline ATALANTA & Róg Afryki & 22 & 19 XII 2008 & 14 IV 2018 & 31 III 2019 \\
\hline SEA GUARDIAN & Morze Sródziemne & 191 & 29 IX 2016 & 22 III 2018 & 31 III 2019 \\
\hline OPERACJA SOPHIA & Morze Śródziemne & 200 & 1 X 2015 & 14 VI 2018 & 30 VI 2019 \\
\hline MINURSO & Afryka Zachodnia & 3 & 16 X 2013 & 16 X 2013 & bez limitu \\
\hline UNSMIL & Libia & 2 & 16 IX 2011 & 13 IX 2018 & 15 IX 2019 \\
\hline
\end{tabular}

Źródło: Einsatzzahlen - die Stärke der deutschen Kontingente, Bundesministerium der Verteidigung, Berlin, 11 I 2019.

Z obserwacji dyplomatycznych podróży niemieckich elit do Afryki wynika, że po wybuchu Arabskiej Wiosny priorytetowym celem wizyt są państwa Afryki Północnej. Ursula von der Leyen przede wszystkim odwiedzała Mali. W październiku 2016 roku kanclerz Merkel udała się do Mali, Nigru i Etiopii, a Frank-Walter Steinmeier do Nigerii. Rok 2017 został ogłoszony w Niemczech rokiem Afryki. W styczniu 2017 roku minister ds. współpracy gospodarczej i rozwoju Gerd Müller zainaugurował Plan Marshalla w sprawie Afryki. Ta inicjatywa stała się punktem programu niemieckiej prezydencji w grupie G-20. W jej trakcie odbył się 12 i 13 VI 2017 roku szczyt „Partnerstwo z Afryką". Niemieckie inicjatywy potwierdzają popularność postulatu empowerment and enable the Africans, który wydaje się ryzykowny i trudny do zrealizowania ze względu na wewnętrzne konflikty w Afryce, głównie terroryzm.

\section{Bibliografia}

Afrikapolitische Leitlinien der Bundesregierung (2014).

Bernau O. (2017), Angelplatz Afrika: Das Ende der Entwicklungshile?, „Blätter für deutsche und internationale Politik“, $\mathrm{nr} 9$.

Demokratische Republik Kongo - EUFOR RD Kongo, http://www.einsatz.bundeswehr.de/portal/a/ einsatzbw/start/abgeschlossene_einsaetze/demokr_rep_kongo/eufor_rd_congo, 12 I 2018.

Deutschland und Afrika: Konzept der Bundesregierung, 2011.

Durotoye A. (2001), Nigerian-German relations. The role of political culture, Leipzig.

Eid U., Asche H. (2003), Deutsche Interessen und Pflichten in Afrika, 26 XI https://www.epo.de/ index.php?option=com_content\&view=article\&id=113:deutsche-interessen-und-pflichtenin-afrika\&catid=27\&Itemid=69, 2 I 2019. 
Einsatz für Afrika (2016), „Internationale Politik“, nr 11/12.

Engel U. (2000a), Briefing: Still in search of a political agenda: Germany's Africa policy under the red-green government, 1998-1999, "African Affairs", nr 99.

Engel U. (2007), Germany and Africa. Musing over MDGs and Militarizing Multilateralism, https:// www.academia.edu/14184817/2007_Germany_and_Africa._Musing_Over_MDGs_and_ Militarization_of_Multilateralism, 12 I 2018.

Engel U. (2000b), Halbzeitbilanz: Wandel und Kontinuität deutscher Afrikapolitik unter der rotgrünen Regierung 1998-2000, ,Journal für Entwicklungspolitik“, XVI/2.

Engel U. (2000c), The G8 and Germany's Africa Policy: A Case of Hegemonic Mainstreaming, https://www.academia.edu/12788663/_2010_The_G8_and_Germany_s_Africa_Policy_A_ Case_of_Hegemonic_Mainstreaming, 12 I 2018.

Für eine kohärente Politik der Bundesregierung gegenüber fragilen Staaten - Ressortübergreifende Leitlinien, 2012 Report 2014: Germany's „Act of Liberation“, https://www.bmz.de/de/zentrales_downloadarchiv/Presse/leitlinien_fragile_staaten.pdf.

https://www.german-foreign-policy.com/en/news/detail/6191/.

Gesamtkonzept der Bundesregierung: Zivile Krisenprävention, Konfliktlösung und Friedenskonsolidierung, 2000.

Gradziuk A. (2003), Szczyt G8 w Evian-les-Bains we Francji, „Biuletyn PISM”, 5 VI.

Grill B. (2012), Ach, Afrika. Berichte aus dem Inneren eines Kontinents, München.

Hanisch M. (2015), On German Foreign and Security Policy - Determinants of German Military Engagement in Africa Since 2011, Berlin.

Koepf T. (2015), Deutschland auf der Suche nach einer Afrika-Strategie, Note du Cerfa nr 119.

Kohl H. (2007), Erinnerungen 1990-1994, München.

Kurthen H., Schöne H. (2018), Außenpolitische Handlungsregeln in Deutschland. Ergebnisse aus Experteninterviews während der Libyenkrise 2011, „Zeitschrift für Außen und Sicherheitspolitik“, nr 11.

Von Naß M., Grill B. (2005), Wir brauchen Afrika, „Die Zeit“, 13 X.

Møller A I. S. (2015), Driving Forces of German Military Participation in Multilateral Missions in Africa, Oslo.

Mükke L. (2009), Allein auf weiter Flur: Korrespondenten in Afrika, „Aus Politik und Zeitgeschichte", $\mathrm{nr} 34 / 35$.

Richter L. (2005), Deutsche Interessen in Afrika? Langfrisiges Engagement auf dem „, Kontinent der Potenziale”, „Konrad Adenauer Stiftung-Auslandsinformationen”, nr 8.

Sattar M. (2009), ,....und das bin ich!“ Guido Westerwelle. Eine politische Biographie, München.

Schöllgen G. (2015), Gerhard Schröder. Die Biographie, München.

Schukraft C. (2007), Die Afrikapolitik Deutschlands-von der „Freundlichen Vernächlässigung “ hin zu einem stärkeren Engagement, w: G. Müller-Brandeck-Bocquet, S. Schmidt, C. Schukraft, U. Keßler, P. Grieg, Die Afrikapolitik der Europäischen Union. Neue Ansätze und Perspektiven, Budrich.

Tetzlaff R. (2018), Afrika. Eine Einführung in Geschichte, Politik und Gesellschaft, Wiesbaden.

Wojnicz L. (2014), Wplyw procesów europeizacyjnych $w$ Afryce na przyktadzie cywilnych misji Unii Europejskiej w Demokratycznej Republice Konga, „Rocznik Integracji Europejskiej”, nr 8.

\section{Streszczenie}

W artykule analizowano zmiany polityki Niemiec wobec Afryki w obszarze bezpieczeństwa, które cechuje odchodzenie od kultury wstrzemięźliwości w kierunku polityki odpowie- 
dzialności, postulowanej m.in. przez prezydenta Joachima Gaucka oraz minister ds. obrony Ursulę von der Leyen. Niemiecka polityka bezpieczeństwa wobec Afryki opiera się na zasadzie multilateralizmu i wynika ze zobowiązań sojuszniczych, mimo że niemieckie społeczeństwo sceptycznie ocenia skuteczność wysyłania żołnierzy do Afryki.

Słowa kluczowe: multilateralizm, bezpieczeństwo, relacje niemiecko-afrykańskie

\section{German's security engagement in Africa - selected issues}

\section{Summary}

The subject of the research is change of Germans policy towards Africa in security area from culture of restraint to the responsibility policy (proposal of president Joachim Gauck and security minister Ursula von der Leyen). German security policy towards Africa based on multilateralism and allied obligations. Germans society tends to be skeptical about effectiveness of sending german armed forces to Africa.

Key words: multilateralism, security, german-african ralations 